\title{
Mapping soil organic carbon under erosion processes using remote sensing
}

\author{
Azamat SUlEYMANOV', Ilyusya GABBASOVA ${ }^{1}$, Ruslan SULEYMANOV ${ }^{1,2}$, \\ Evgeny ABAKUMOV ${ }^{3,4}$, Vyacheslav POLYAKOV ${ }^{3}$ and Peter LIEBELT ${ }^{5}$
}

\begin{abstract}
This study aimed to map soil organic carbon under erosion processes on an arable field in the Republic of Bashkortostan (Russia). To estimate the spatial distribution of organic carbon in the Haplic Chernozem topsoil, we applied Sentinel-2A satellite data and the linear regression method. We used 13 satellite bands and 15 calculated spectral indices for regression modelling. A regression model with an average prediction level has been created $\left(R^{2}=0.58, R M S E=0.56, R P D=1.61\right)$. Based on the regression model, cartographic materials for organic carbon content have been created. Water flows and erosion processes were determined using the calculated Flow Accumulation model. The relationship between organic carbon, biological activity, and erosion conditions is shown. The ${ }^{13} \mathrm{C}$-NMR spectroscopy method was used to estimate the content and nature of humic substances of different soil samples. Based on the ${ }^{13} \mathrm{C}-\mathrm{NMR}$ analysis, a correlation was established with the spectral reflectivity of eroded and non-eroded soils. It was revealed that the effect of soil organic carbon on spectral reflectivity depends not only on the quantity but also on the quality of humic substances and soil formation conditions.
\end{abstract}

Keywords: Soil organic carbon, remote sensing, sentinel, erosion, humic acids,13C-NMR

Received August 2020; Accepted February 2021

\section{Introduction}

Water erosion is one of the most dangerous processes due to the transformation of climatic conditions and anthropogenic impacts. Erosion of agricultural lands and subsequent fertility decline is one of the reasons for the abandonment of lands (BAUDE, M. et al. 2019; Suleymanov R. et al. 2020a). This is especially true for the southern regions of Russia, where degradation processes proceed at an accelerated pace (KatTsov, V.M. 2017). The Republic of Bashkortostan is located in the southern part of the Ural Mountains and characterized by actively occurring processes of water and wind erosion (SовоL, N.V. et al. 2015; Gabbasova, I.M. et al. 2016; Suleymanov, R. et al. 2019). The size of erosion rates can be judged by the following data: the land fund of the republic is $142,970 \mathrm{~km}^{2}$, agricultural land occupies 73,430 $\mathrm{km}^{2}(51.37 \%), 36,000 \mathrm{~km}^{2}$ are erosion-hazardous $(25.18 \%), 33,000 \mathrm{~km}^{2}$ are exposed to water erosion $(23.08 \%)$, wind erosion $-10,500 \mathrm{~km}^{2}$ $(7.35 \%)$, the joint action of water and wind erosion $-120 \mathrm{~km}^{2}(0.08 \%)$ (GabBasova, I.M. et al. 2016; Suleymanov, R. et al. 2020b).

\footnotetext{
${ }^{1}$ Laboratory of soil science, Ufa Institute of Biology, Ufa Federal Research Centre, Russian Academy of Sciences, 450054, pr. Oktyabrya 69, Ufa, Russia. Correspondent author's e-mail: filpip@yandex.ru

${ }^{2}$ Department of Geodesy, Cartography and Geographic Information Systems,, Bashkir State University, 450076, Zaki Validi 32, Ufa, Russia. E-mail: soils@mail.ru

${ }^{3}$ Faculty of Biology, Department of Applied Ecology, Saint Petersburg State University, 199034, 16th line of Vasilyevsky Island 29, Saint Petersburg, Russia. E-mail: e_abakumov@mail.ru

${ }^{4}$ Laboratory of Microbiological Monitoring and Bioremediation of Soils, All-Russia Insitute for Agricultural Microbiology, 196608, sh. Podbelsky 3, St. Petersburg, Russia

${ }^{5}$ Martin Luther University Halle-Wittenberg, 06120, Von-Seckendorff-Platz 4, Halle, Germany.

E-mail: peter.liebelt@geo.uni-halle.de
} 
Remote sensing (RS) is a useful tool in soil researches (MuldER, V.L. et al. 2011; SAVIN, I.Yu. et al. 2019). Multi- and hyperspectral images from unmanned aerial vehicles, aircraft, and space satellites are used for different scientific tasks. The active use of satellite data in last years is facilitated by improved spatial resolution, a large data set (multi-year image archives), a short interval, free access to satellite images (Sentinel, Landsat, and others) (Prudnikova, E.Yu. and SAvin, I.Yu. 2015; Angelopoulou, T. et al. 2019). RS methods are more cost-effective and allow to cover large areas.

The integration of RS and GIS is a valuable tool for research, digital mapping, and modelling of erosion processes (LeH, M. et al. 2013; Guo, B. et al. 2018; NАмРAк, H. et al. 2018; Suleymanov, A.R. 2019; YANG, X. et al. 2020). Study soil erosion based on RS and GIS methods are currently being actively studied throughout the world (Desprats, J.F. et al. 2013; WANG, L. et al. 2013; Panagos, P. et al. 2015; Yermolaev, O.P. 2017; Golosov, V. et al. 2018; FrankL, A. et al. 2018; Sepuru, T.K. and Dube, T. 2018; Phinzi, K. and Ngetar, N.S. 2019; Magliulo, P. et al. 2020). Erosion processes are directly related to soil organic carbon (SOC) content. In a review article by ANGelopoulou, T. et al. (2019), about evaluating SOC based on RS data, the authors conclude that recent advances in machine learning can help improve the overall accuracy and reliability of models. Thus, many studies confirm the successful use of satellite data in the study of transformation processes and automated mapping of SOC content (Mounzen, A.M. et al. 2007; Bartholomeus, H. et al. 2008; Dube, T. et al. 2018; GHOLIzADEH, A. et al. 2018; BHunia, G.S. et al. 2019; CAstaldi, F. et al. 2019; CHen, D. et al. 2019; Dou, X. et al. 2019; VAudour, E. et al. 2019).

According to some studies (Ben-Dor, E. et al. 1997; Viscarra Rossel, R.A. et al. 2006b; Nocita, M. et al. 2015; CAstaldi, F. et al. 2018, 2019), in order to model and predict the SOC content, recommended to use spectral characteristics located in the visible range at $450,590,664 \mathrm{~nm}$, as well as the characteristics of the invisible range in the short-wave infrared SWIR range - between 1,600 and 1,900 nm and about 2,100 and 2,300 nm. At satellite Sentinel$2 \mathrm{~A}$, the bands of the visible spectrum B2, B3, B4 (490, 560, and $665 \mathrm{~nm}$, respectively) and the invisible range in the SWIR region are $\mathrm{B} 11$ and B12 (1,610 and 2,190 nm, respectively). Thus, as Sentinel-2A has a close correspondence of the spectral characteristics, it allows the use of data for the estimation and modelling of SOC content in topsoil.

Soil colour is one of the key indicators for digital SOC mapping using RS (Mulder, V.L. et al. 2011). The qualitative and quantitative composition of humic acids in turn, affects the colour of the soil (VIscarra Rossel, R.A. et al. 2006a). Thus, humic substances are an indicator of the spectral reflectivity of the soil, with which a remote evaluation is possible. At the same time, soil organic matter (SOM) plays an important role in maintaining a good soil structure and directly affects the nature of erosion processes. SOM is responsible for the content of organic substances, nutrients, the activity of microorganisms, moisture retention.

Nuclear Magnetic Resonance (NMR) spectroscopy is a highly accurate physical and chemical tool for determining the composition and structure of soil organic matter (QUIDEAU, S.A. et al. 2000; Cнuкov, S.N. et al. 2017, 2018; Polyakov, V. and Авакumov, E.V. 2020). The ${ }^{13} \mathrm{C}-\mathrm{NMR}$ spectroscopy method allows to study the structural and compositional features of humic acid preparations of eroded soils, which will help to understand the ongoing processes of humification, degradation, and SOC transfer on eroded lands (Simpson, M.J. et al. 2008; Авакumov, E.V. et al. 2013; Rumpel, C. et al. 2014; Conte, P. et al. 2017).

Currently, in conditions of active anthropogenic impact, it is necessary to conduct local studies to understand the processes of transformation and degradation of SOC. Thus, our work aims to map SOC content, estimate and study transport processes on an eroded agricultural field, using Sentinel-2A satellite data, ${ }^{13} \mathrm{C}-\mathrm{NMR}$ spectroscopy, and geomorphological methods. The developed methodology will allow us to simulate and evaluate the SOC content in the topsoil of agricultural land for monitoring and mapping. 


\section{Materials and methods}

\section{Site description}

The study area is cropland (1,400 hectares) in long-term agricultural use located in the south of Russia, in the Zilair region of the Republic of Bashkortostan (Figure 1). The site is characterized by ploughing with a turnover of the soil layer at a depth of $10-15 \mathrm{~cm}$. Wheat (Triticum aestivum) is predominantly growing on the plot. The cropland is located on gentle slopes of various exposures. According to geomorphometric analysis based on digital elevation model (DEM), the height of the study area varies from $460 \mathrm{~m}$ in the north-western part of the site to $377 \mathrm{~m}$ above sea level in the south-eastern part. The area mainly consists of slopes of up to $4^{\circ}$. The steepest sites are located in the southern, south-western, and northern parts of the site. The water erosion processes take place in the southern and northern parts of the territory. Wind erosion processes are also observed at the site.
The climate of the region is arid or slightly arid. The average annual air temperature is $1.4{ }^{\circ} \mathrm{C}$, the average annual rainfall is 379 $\mathrm{mm}$. According to the World Reference Base (WRB) for soil resources (IUSS Working Group WRB, 2014), the soil of the study site is characterized as Haplic Chernozems. The parent rocks are the eluvial-deluvial carbonate clays and heavy loams, as well as the eluvium of sandy schists.

\section{Soil samples}

The soil sampling work was carried out in October 2018 (49 full-profile sections and 5 pits). The soil samples were identified by satellite images to choose areas with different spectral reflectivity and erosion conditions. The exact coordinates of each soil point were identified using a global positioning system (GPS) with an accuracy of $\pm 3 \mathrm{~m}$. The crop has already been harvested at this time. Samples for the analysis SOC content were taken from

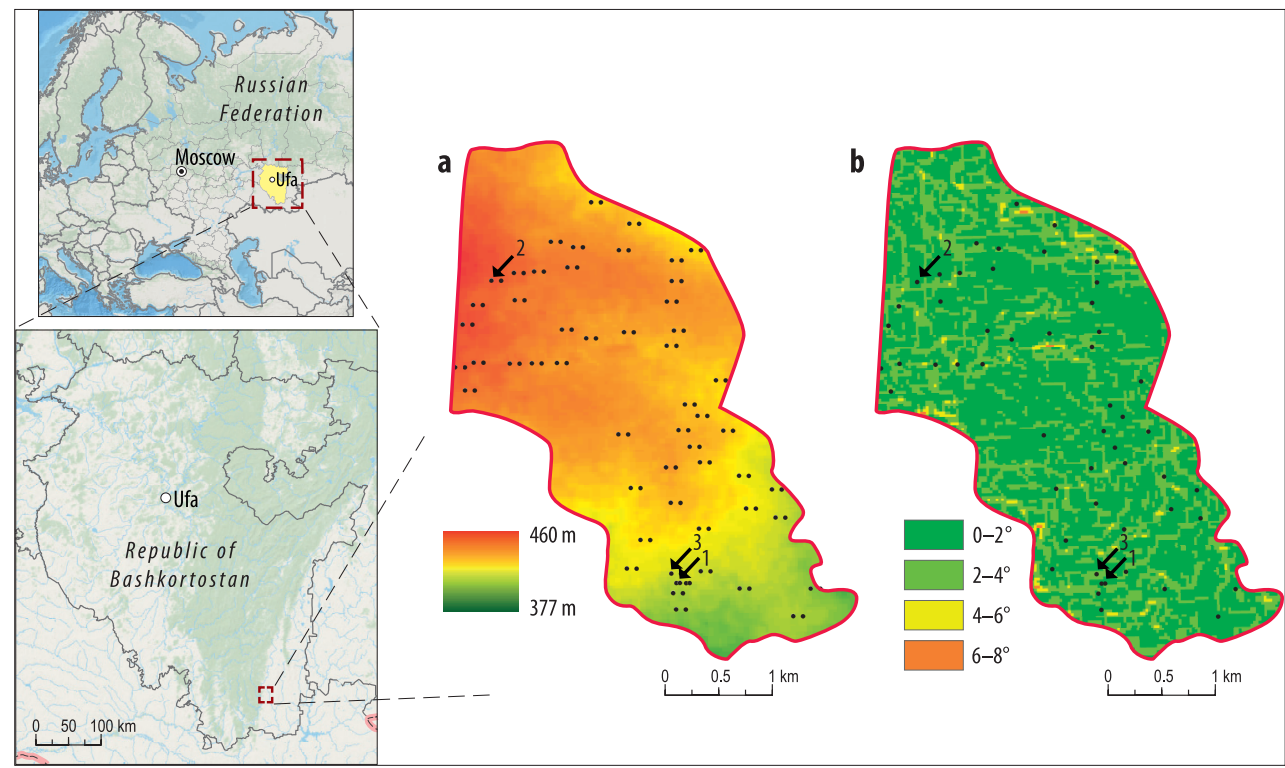

Fig. 1. Map of the study area (left) and spatial distribution of soil samples $(\mathrm{n}=54)$. $-\mathrm{a}=$ elevation map in metres a.s.l.; $b=$ slope map in degrees. Arrows and numbers (1-3) indicate samples for ${ }^{13} \mathrm{C}-\mathrm{NMR}$ spectroscopy analysis. 
the topsoil $(0-10 \mathrm{~cm})$. The carbon content was determined using the Tyurin method with colourimetric termination, according to Orlov and Grindel (Arinushrina, E.V. 1970; SoKolov, A.V. 1975). The microbiological activity of soils, the basal respiration, using incubation chambers was determined by standard protocol (LAL, R. et al. 2001). Soil basal respiration is defined as the steady rate of respiration in soil, which originates from the mineralization of organic matter.

\section{Remote sensing data}

The Sentinel-2 satellite free-access dataset (Level-2A processing) was used for the study. The satellite data contains 13 spectral bands with a spatial resolution of 10 to $60 \mathrm{~m}$. (Table 1). The cloud-free scenes from 02.10.2018 were selected for the study. This scene time is selected for work with bare soil and reduce vegetation impact. Then images went through the stages of atmospheric and radiometric correction using the module "Semi-Automatic Classification Plugin" in QGIS 3.6.0.

For more complex analysis, the most popular spectral indices for predicting soil attributes have been selected. The following indices based on the combination of Sentinel-2A satellite bands were calculated: Normalized Difference Vegetation Index (NDVI), Transformed Vegetation Index
(TVI), Enhanced Vegetation Index (EVI), Soil Adjusted Total Vegetation Index (SATVI), SoilAdjusted Vegetation Index (SAVI), Moisture Stress Index (MSI), Green Normalized Difference Vegetation Index (GNDVI), GreenRed Vegetation Index (GRVI), Land Surface Water Index (LSWI), Modified Soil Adjusted Vegetation Index (MSAVI), the Second Modified Soil Adjusted Vegetation Index (MSAVI2), Brightness Index (BI), the Second Brightness Index (BI2), Redness Index (RI), Color Index (CI). The index formulae and descriptions are presented in Table 2.

Vegetation indices are important predictors and are actively used in the modelling and mapping of soil properties. For example, Bhunia, G.S. et al. (2019) successfully applied NDVI and BSI indices using a multivariate regression approach for SOC mapping. Gholizadeh, A. et al. (2018) showed that GNDVI and SATVI indices provided the strongest correlation with SOC on agricultural plots. Also, several studies conclude that vegetation indices are the most important variables in predicting soil properties (Gopp, N.V. et al. 2017; Chen, D. et al. 2019; EmAdi, M. et al. 2020).

\section{${ }^{13} \mathrm{C}-\mathrm{NMR}$ spectroscopy}

Soil samples for spectroscopy were selected according to the following parameters: a sample from a site of study area without water

Table 1. Sentinel-2A bands specifications

\begin{tabular}{l|c|c|c|c}
\hline Band & Spectral range, $\mathrm{nm}$ & Spatial resolution, $\mathrm{m}$ & Spectral position, $\mathrm{nm}$ & Bandwidth, $\mathrm{nm}$ \\
\hline B1 & $433-453$ & 60 & 443 & 20 \\
B2 & $458-523$ & 10 & 490 & 65 \\
B3 & $543-578$ & 10 & 560 & 35 \\
B4 & $650-680$ & 10 & 665 & 30 \\
B5 & $698-713$ & 20 & 705 & 15 \\
B6 & $733-748$ & 20 & 740 & 15 \\
B7 & $773-793$ & 20 & 783 & 20 \\
B8 & $785-900$ & 10 & 842 & 115 \\
B8a & $855-875$ & 20 & 865 & 20 \\
B9 & $935-955$ & 60 & 945 & 20 \\
B10 & $1,360-1,390$ & 60 & 1,380 & 30 \\
B11 & $1,565-1,655$ & 20 & 1,610 & 90 \\
B12 & $2,100-2,280$ & 20 & 2,190 & 180 \\
\hline
\end{tabular}




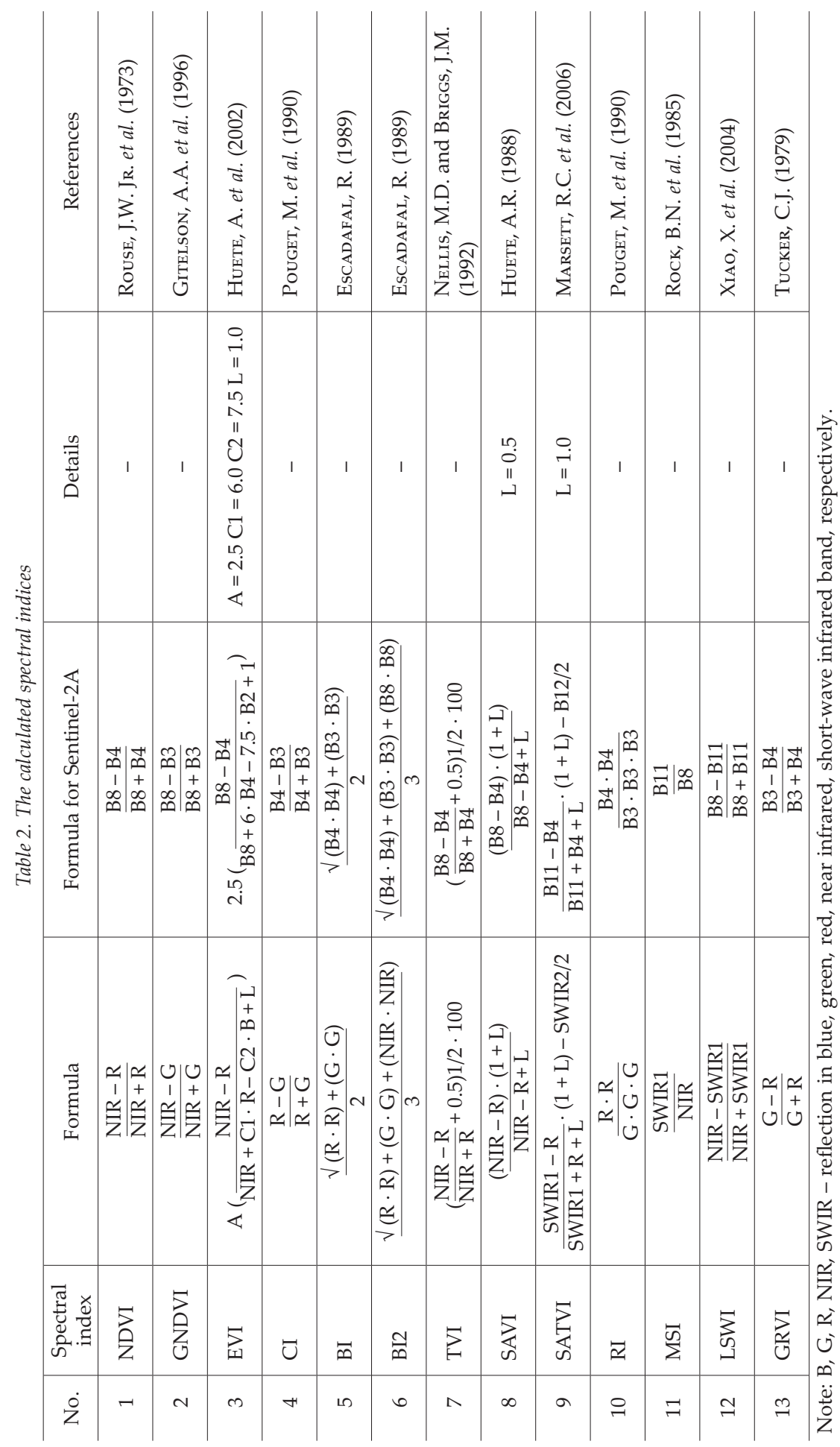


erosion processes, with erosion processes and erosion sediment. Samples from the site without water erosion were taken at the top in the northern part of the site. Samples from the plot of erosion processes and sediment were taken at the southern part of the field (see Figure 1).

Humic acids (HAs) were extracted according to a published IHSS protocol (SwIFT, R.S. 1996). Solid-state $\mathrm{CP} / \mathrm{MAS}{ }^{13} \mathrm{C}-\mathrm{NMR}$ spectra of HAs were obtained by Bruker Avance 500 NMR spectrometer. The repetition delay was $3 \mathrm{sec}-$ onds. The number of scans was 6,500-29,000. Contact time is $0.2 \mu \mathrm{s}$.

Various molecular fragments were identified by $\mathrm{CP} / \mathrm{MAS}{ }_{13} \mathrm{C}-\mathrm{NMR}$ spectroscopy (Table 3): carboxyl (-COOR); carbonyl $(-\mathrm{C}=\mathrm{O})$; $\mathrm{CH}_{3}-, \mathrm{CH}_{2}-, \mathrm{CH}-$ aliphatic; -C-OR alcohols, esters, and carbohydrates; phenolic ( $\mathrm{Ar}-\mathrm{OH})$; quinone $(\mathrm{Ar}=\mathrm{O})$; aromatic $(\mathrm{Ar}-)$, which indicates the great complexity of the structure of HAs and the poly-functional properties that cause their active participation in soil processes (LoDygin, E.D. et al. 2014).

To standardize the quantitative characteristics of humic acid macromolecules, the following parameters were used: carbon ratio of aromatic structures to aliphatic structures, the decomposition rate of organic matter (C-Alkyl/ O-Alkyl), and humic acid hydrophobicity integral index (AL h,r + AR h,r, \%).

\section{Geomorphometric analysis}

The geomorphometric analysis of the territory was carried out using the QGIS and SAGA GIS based on a digital elevation model (DEM) with a resolution of $30 \mathrm{~m}-\mathrm{NASA}^{\prime} \mathrm{s}$
Shuttle Radar Topography Mission (SRTM) (https://www2.jpl.nasa.gov/srtm). Maps of heights, slopes, and flow accumulation models were created. The Flow accumulation model determines the natural water direction for every pixel in a DEM. Flow accumulation operation calculates the total number of pixels that will drain into certain areas (JENSON, S.K. and Domingue, J.O. 1988).

\section{Statistical analysis}

Linear Least Squares Regression analysis was used to establish relationships between the values of satellite data and SOC content. A model was built separately for each band and index. Due to the limited number of soil samples available, a leave-one-out cross-validation procedure was applied (KHAN, J. et al. 2010; VAudour, E. et al. 2019). The advantage of leave-one-out is that each sample participates exactly once in control from all ' $\mathrm{n}$ ' samples within the dataset. This procedure was repeated for all n samples (Gomez, C. et al. 2012).

Prediction accuracy was evaluated by the RMSE and the $\mathrm{R}^{2}$ values. The model with the lowest RMSE and highest $\mathrm{R}^{2}$ values was considered as the most applicable or ideal model (JABER, S.M. et al. 2011). The $\mathrm{R}^{2}$ was determined by the following classification (VAudour, E. et al. 2019): models with $\mathrm{R}^{2}<$ 0.4 show a poor or very low level of predictive ability; values of $0.5<\mathrm{R}^{2}<0.7$ indicate models with an average level of forecasting; models with $\mathrm{R}^{2}>0.7$ are highly predictive.

The accuracy of the model was also determined by the classification, where RPD (re-

Table 3. Chemical shifts of atoms of the 13C molecular fragments of humic acids

\begin{tabular}{c|l}
\hline Chemical shift, ppm & \multicolumn{1}{c}{ The type of molecular fragments } \\
\hline $0-46$ & C, H-substituted aliphatic fragments \\
$46-60$ & $\begin{array}{l}\text { Methoxy and O, N-substituted aliphatic fragments } \\
\text { Aliphatic fragments doubly substituted by heteroatoms (including carbohydrate) } \\
\text { and methine carbon of ethers and esters }\end{array}$ \\
$60-110$ & $\begin{array}{l}\text { C, H-substituted aromatic fragments; O, N-substituted aromatic fragments } \\
\text { Carboxyl groups, esters, amides, and their derivatives } \\
110-160\end{array}$ \\
$160-185$ & Quinone groups; Groups of aldehydes and ketones \\
\hline
\end{tabular}


sidual prediction deviation) was calculated. RPD values $<1.0$ indicate a poor predictive model; $1.0<\mathrm{RPD}<1.4$ indicate a weak model; $1.4<\mathrm{RPD}<1.8$ indicate a good model that can be used for evaluation; $1.8<\mathrm{RPD}<2.0$ indicate a good model; $2.0<\mathrm{RPD}<2.5$ show a very good model and values RPD $>2.5$ indicate the excellent quality of the predictive model (CHANG, C.-W. et al. 2001; ViscARrARossel, R.A. et al. 2006b).

The statistical analysis was performed using the "caret" package in R 4.0.3 ( $\mathrm{R}$ Development Core Team, 2015) and RStudio (version 1.3.1093) (RStudio, 2015). The IDW and ordinary kriging interpolation maps were created using standard tools in QGIS.

\section{Results and discussion}

General statistics of soil properties: mean, minimum, maximum, standard deviation (SD), coefficient of variation (CV) are shown in Table 4. The values of SOC changed in the range from 1.93 to 5.52 per cent. The depth of the humic horizon is 20 to $70 \mathrm{~cm}$, mean value $-46.32 \mathrm{~cm}$. Spearman's correlation (R) between SOC content in the 0-10 cm layer and the topsoil is 0.59 .

The regression analysis (Figure 2) showed that the maximum values of correlation coefficients $R=0.78, R^{2}=0.61$ were detected at the invisible range B12 band (SWIR, the spatial resolution of $20 \mathrm{~m}$ and a spectral range of
Table 4. Statistics description of Corg in the 0-10 cm layer and the depth of the humic horizon

\begin{tabular}{l|c|c}
\hline Parameter & Corg, \% & $\begin{array}{c}\text { Depth of humic } \\
\text { horizon, cm }\end{array}$ \\
\hline \multicolumn{3}{|c}{$\mathrm{n}=54$} \\
Mean & 3.72 & 46.32 \\
Min & 1.93 & 20,00 \\
Max & 5.52 & 70,00 \\
SD & 0.88 & 9.49 \\
CV, \% & 23.65 & 20.49 \\
\hline
\end{tabular}

2,190 nm). The SWIR band of Sentinel-2A for SOC mapping shows good results in other croplands studies. Thus, in the GHolizadeH, A. et al. (2018) study in the Czech Republic, the authors obtained the highest correlation values (R) of B4, B5, B11, and B12 bands. The correlation of the $\mathrm{B} 12$ band ranged from 0.29 to 0.69 , depending on the field.

The calculated spectral indices (see Table 2) showed less reliable correlation results (see Figure 2). The highest correlations were obtained using NDVI $\left(\mathrm{R}=0.68, \mathrm{R}^{2}=0.46\right)$, TVI $\left(R=0.67, R^{2}=0.45\right)$, and EVI $\left(R=0.60, R^{2}\right.$ $=0.36)$, which use bands of visible red and near-infrared range in their equations.

Attempting to diagnose the spatial distribution of the topsoil using bands and indices did not lead to reliable results. Since there is a correlation between the SOC content and the topsoil depth, the highest values in regression analysis are also shown by the B12 band $\left(R=0.51, R^{2}=0.26\right)$.

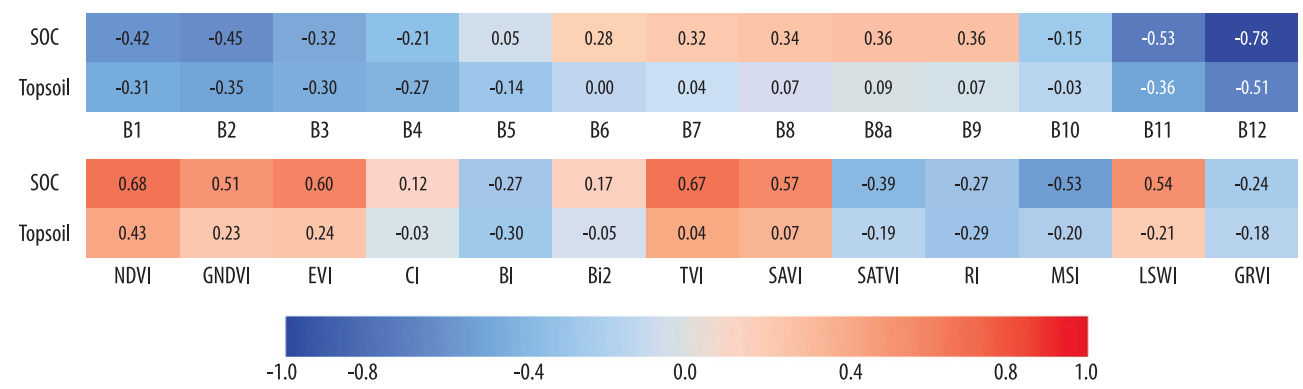

Fig. 2. The correlograms (Spearman correlation) of SOC and topsoil at bands of Sentinel-2A and calculated spectral indices. The correlation coefficients are significant at a level of 0.05 . 
The $\mathrm{B} 12$ band is the most appropriate variable for prediction SOC, according to RMSE and $\mathrm{R}^{2}$ values (Table 5). We obtained the model with RMSE $=0.56, \mathrm{RPD}=1.61$, and $\mathrm{R}^{2}=0.58$. According to the classification, this model characterizes as a good model with an average prediction level (VAUdour, E. et al. 2019). The RPD values in GHolizadeH, A. et al. (2018) were 1.60-1.92 depending on the territory; similar results using Sentinel-2 data were obtained by VAudour, E. et al. (2019) on the study territory of France -1.51 . The RPD results of CAstaldi, F. et al. (2019) were values 1.1-2.6 on the study areas in Germany, Belgium, and Luxembourg.

All other Sentinel bands and spectral indices are characterized by a very low level of predictive ability using a cross-validation procedure. However, the vegetation indices NDVI and TVI show values $R^{2}=0.42$. This approximation of the model to the average prediction level can be considered in future studies in similar areas and with a larger dataset.

The SOC content map based on the obtained regression equation was created using the B12 band of the satellite. Additionally, the SOC maps were created using the IDW and ordinary kriging methods to verify the spatial distribution based on the regression equation (Figure 3).

The comparative analysis of three models (regression analysis, IDW, ordinary kriging)

Table 5. Cross-validation performance statistics

\begin{tabular}{l|c|c|l|c|c}
\hline Band & RMSE & $\mathrm{R}^{2}$ & Index & RMSE & $\mathrm{R}^{2}$ \\
\hline B1 & 0.81 & 0.11 & NDVI & 0.66 & 0.42 \\
B2 & 0.81 & 0.14 & GNDVI & 0.77 & 0.21 \\
B3 & 0.86 & 0.04 & EVI & 0.72 & 0.31 \\
B4 & 0.88 & 0.00 & CI & 0.89 & 0.04 \\
B5 & 0.89 & 0.22 & BI & 0.87 & 0.02 \\
B6 & 0.86 & 0.03 & BI2 & 0.89 & 0.00 \\
B7 & 0.85 & 0.05 & TVI & 0.66 & 0.42 \\
B8 & 0.85 & 0.05 & SAVI & 0.74 & 0.26 \\
B8a & 0.84 & 0.07 & SATVI & 0.82 & 0.10 \\
B9 & 0.85 & 0.06 & RI & 0.87 & 0.02 \\
B10 & 0.89 & 0.02 & MSI & 0.76 & 0.23 \\
B11 & 0.76 & 0.23 & LSWI & 0.76 & 0.24 \\
B12 & 0.56 & 0.58 & GRVI & 0.87 & 0.00 \\
\hline
\end{tabular}

showed that the largest areas with the highest SOC content (4.5-5.5\%) are concentrated in the western, north-western, and northern parts of the investigated field. These areas are characterized by the highest elevation elements with slopes up to $4^{\circ}$. Based on regression analysis, we can also observe small areas with high SOC values in the north and central parts. The areas with the smallest SOC content are located in the south-east, northeast, and central parts of the cropland. These areas are mainly located at heights between $\approx 420$ and $377 \mathrm{~m}$. The areas of maximum topsoil values are located at the top of the plot in the western part and also small areas in the central part. Analysis of SOC and topsoil maps revealed a spatial correlation: areas with layer thicknesses of 50 to $70 \mathrm{~cm}$ are equivalent to areas of SOC content 3.5-5.5 per cent (see Figure 3).

The water flows have been identified using the Flow Accumulation model (Figure 4). The main powerful flows gather throughout the site, forming the main "arteries". The nature and direction of water flows are fully comparable with the nature of the territory relief: the main flows are concentrated in the centre of the site (direction from north-west to south-east), as well as in the northern and southern parts.

When verifying the Flow Accumulation model with field surveys, it was found that the strongest degradation processes occur in the southern part of the territory. This distribution is explained by the lowest part of the site and an increase in slope steepness (up to $6^{\circ}$ ). However, based on the analysis and maps obtained, the SOC content is not defined as homogeneous in the southern part of the area. The southern area is predominantly characterized by an average thickness surface horizon (up to $50 \mathrm{~cm}$ ) and not high SOC content $(1.5-3.5 \%)$. The study region (Trans-Ural steppe zone) is characterized by active wind erosion processes (KHAZIEv, F.KH. 1995). Thus, we can observe small plots with high SOC content (3.5-5.5\%) in areas closer to and along the road due to the accumulation of soil on the leeward side of these barriers (see Figure 3). Nevertheless, this distribution can also be 


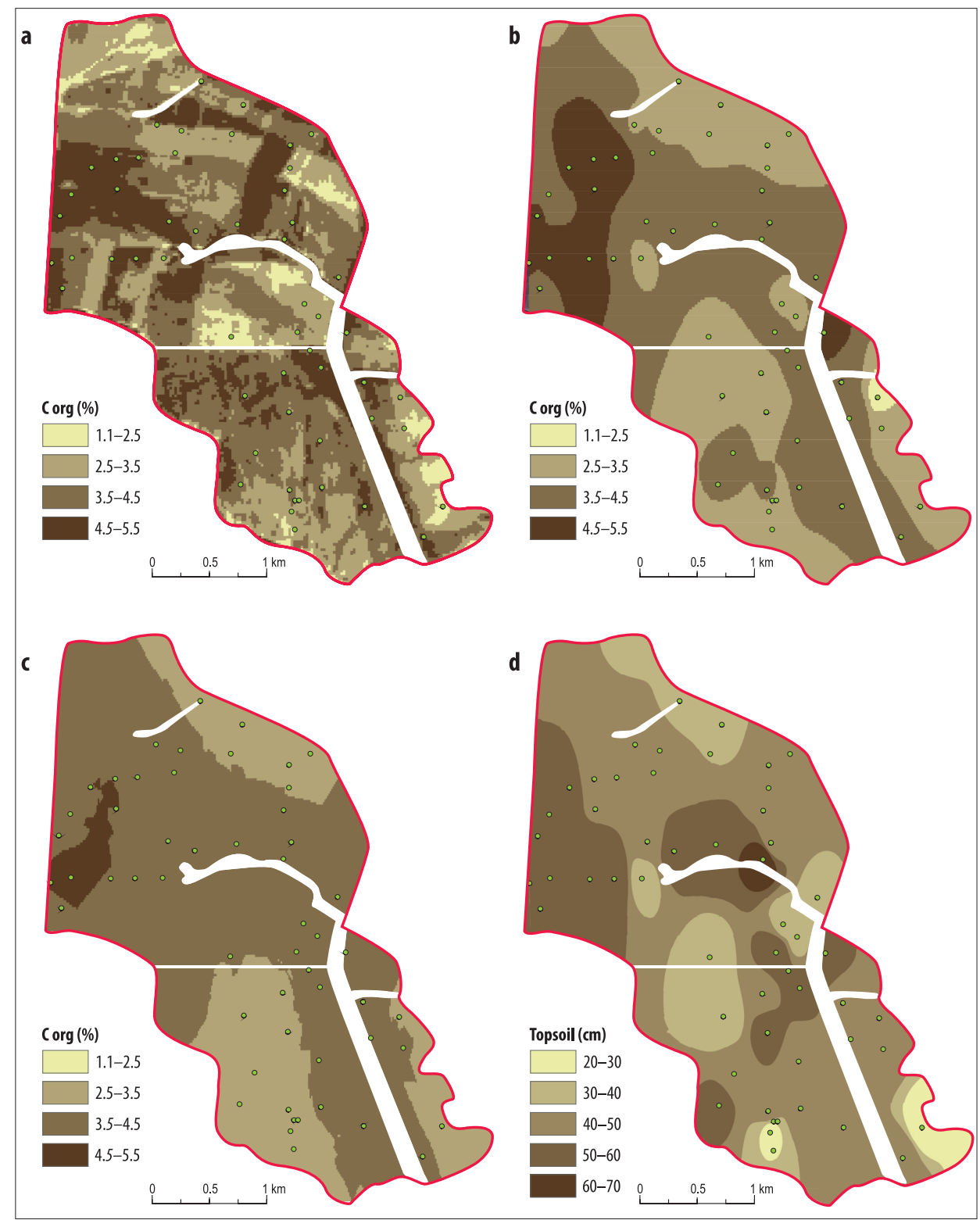

Fig. 3. The SOC content $(0-10 \mathrm{~cm})$ maps created using methods: a = Regression analysis based on satellite band $\mathrm{B} 12 ; \mathrm{b}=\mathrm{IDW} ; \mathrm{c}=$ Ordinary kriging, and topsoil depth map using IDW method; $\mathrm{d}=$ Areas with vegetation and roads are masked by white colour.

caused by the influence of vegetation. We have masked areas with vegetation and roads, but the spatial resolution of the B12 band $(20 \mathrm{~m})$ can still account for this information.
The small areas of high SOC content $(3.5 \%$ and more) are observed in the northern part, near the boundary of the field, which may well be consistent with the transfer of SOC 


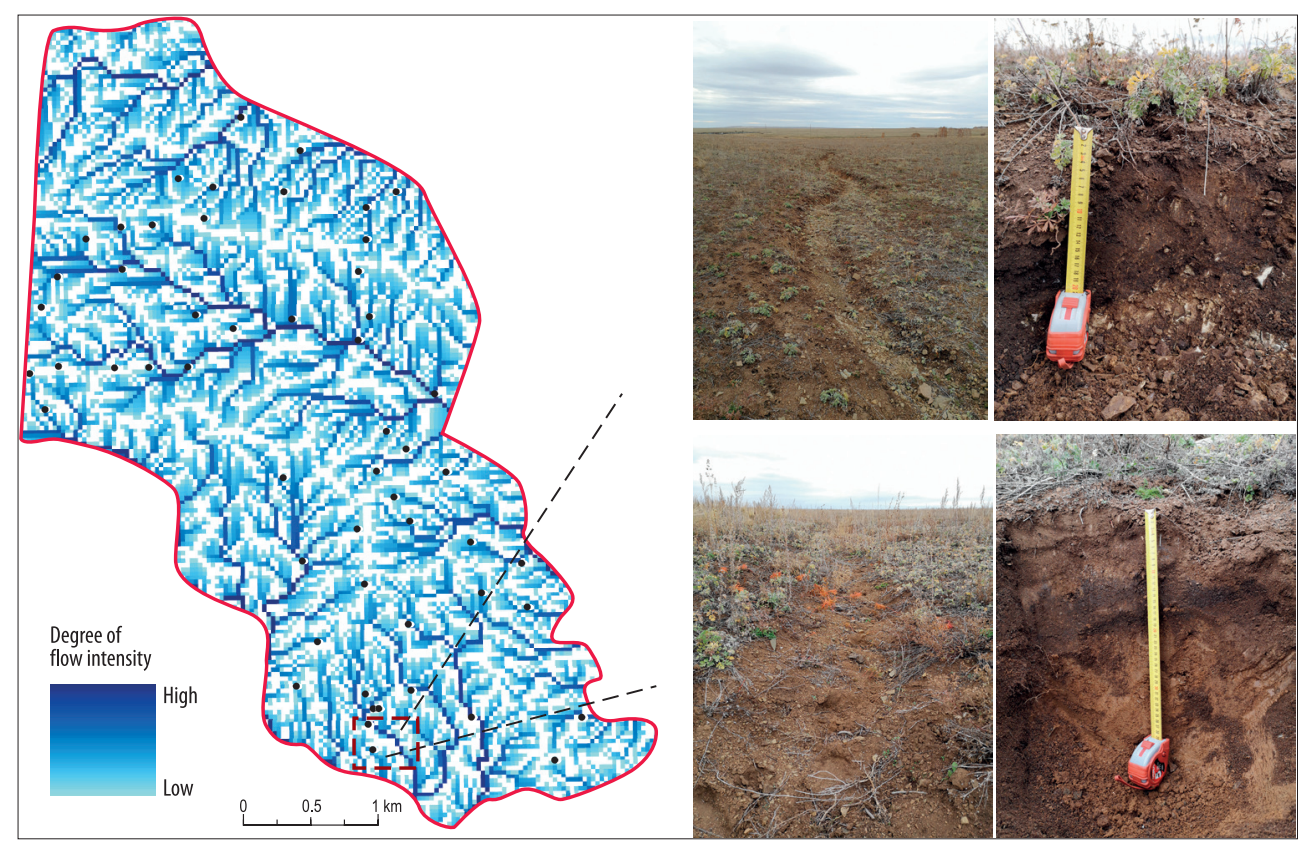

Fig. 4. Flow accumulation model map (left) and examples of rill erosion (right)

from the upper elements of the relief: this area is also characterized by lowering the relief and slopes up to $6-8^{\circ}$. Moreover, water erosion processes are actively occurring in this part of the field.

The lowest value of the microbiological activity of soils in the topsoil was detected in erosion sediment - $12.6 \mathrm{CO}_{2} \mathrm{~g} / 100 \mathrm{~g} \mathrm{day}^{-1}$. Whereas in a non-erosive sample located a few meters from the erosion sediment, basal respiration is equal to $18.8 \mathrm{CO}_{2} \mathrm{~g} / 100 \mathrm{~g}$ day $^{-1}$. The highest values are determined on the upper non-erosion elements of the terrain on average $25 \mathrm{CO}_{2} \mathrm{~g} / 100 \mathrm{~g} \mathrm{day}^{-1}(\mathrm{n}=7, \mathrm{SD}=5)$. Thus, the high microbiological activity is noted in not degradation process areas with the largest SOC content. The lower values of basal respiration are detected in an area vulnerable to erosion processes and the erosive sediment sample.

Verification of eroded and non-eroded soil samples of the south area of the field by ${ }^{13} \mathrm{C}-\mathrm{NMR}$ spectroscopy revealed the following results (Table 6). The sample No 1 (erosion sediment) is characterized by an increase in the aliphatic and oxygen-containing group compared to other samples; the ratio of $\mathrm{AR} / \mathrm{AL}$ is 0.67 . The erosion process led to a decrease in the aromaticity of HAs and the

Table 6. Percentage of carbon in the main structural fragments of HAs from the studied surface soil horizons*

\begin{tabular}{|c|c|c|c|c|c|c|c|c|c|c|c|}
\hline \multirow{2}{*}{ Sample } & \multicolumn{6}{|c|}{ Chemical shifts, ppm } & \multirow{2}{*}{ AR } & \multirow{2}{*}{ AL } & \multirow{2}{*}{$\mathrm{AR} / \mathrm{AL}$} & \multirow{2}{*}{$\begin{array}{c}\text { AL h,r + } \\
\text { AR h,r, \% }\end{array}$} & \multirow{2}{*}{$\begin{array}{c}\mathrm{C}, \mathrm{H}-\mathrm{AL} / \\
\mathrm{O}, \mathrm{N}-\mathrm{AL}\end{array}$} \\
\hline & $0-46$ & $46-60$ & $60-110$ & $110-160$ & $160-185$ & $185-200$ & & & & & \\
\hline 1 & 25 & 6 & 24 & 30 & 10 & 5 & 40 & 60 & 0.67 & 79 & 0.83 \\
\hline 2 & 23 & 6 & 22 & 33 & 12 & 4 & 45 & 55 & 0.82 & 78 & 0.82 \\
\hline 3 & 25 & 6 & 25 & 27 & 11 & 6 & 38 & 62 & 0.61 & 77 & 0.81 \\
\hline
\end{tabular}

*According to 13C-NMR data. Note: $\mathrm{AR}=$ Aromatic fraction; $\mathrm{AL}=$ Aliphatic fraction; $\mathrm{AL} \mathrm{h}, \mathrm{r}+\mathrm{AR} \mathrm{h}, \mathrm{r}=$ Hydrophobicity degree in per cent; $\mathrm{C}, \mathrm{H}-\mathrm{AL} / \mathrm{O}, \mathrm{N}-\mathrm{AL}=$ The degree of decomposition of organic matter. 
removal of stable soil carbon. The formation of aromatic components in the soil is a longterm thermodynamic process. We assume that under conditions of water erosion, the formation of long carbon chains $(-\mathrm{C}-\mathrm{C}-$ ) and oxygen-containing fragments $(\mathrm{O}-\mathrm{CH}-)$ occurs. This distribution also occurs in waterlogging conditions (Lodygin, E.D. et al. 2001, 2014). Water flows prevent the processes of decomposition of plant residues in the soil due to erosion processes. It leads to the acceleration of the transformation processes.

The sample No 2, which is not affected by degradation processes, has more aromatic fragments in its composition than in the samples No 1 and 3. It is distinguished by the accumulation of aromatic and carboxylic fragments; the ratio of $\mathrm{AR} / \mathrm{AL}$ is 0.82 . The increase of these structures in the composition of HAs is associated with the transformation of humification precursors, especially lignin-containing plant residues. In the decomposition of plant residues, up to 30 per cent of lignin enters the soil, which during transformation is included in the composition of HAs in the form of aromatic structural units and carboxylic groups.

The eroded areas are characterized by a decrease in the aromaticity of SOC. There is the removal of dark-coloured materials of SOM and fine soil particles from such areas. They are characterized by less active processes of decomposition of plant residues and microbiological processes, and thus have lower HAs values and are visualized as lighter areas according to maps constructed by regression analysis and interpolation. Such areas of the field are also well identified according to the Flow Accumulation model, which determines the rate of water flow.

The sample No 3 is represented by a little clayey top of the area from which the sheet erosion started. According to NMR spectroscopy, more aliphatic fragments of HAs are formed here - AR/AL (0.61). Clay formations have a high heat capacity and moisture retention capacity (АвU-НАмdeH, N.H. 2003; RozhKov, V.A. 2006). However, such formations are often quite dense aggregates in dry places. This soil structure affects the pene- tration and development of the root system, soil water and air movement, $\mathrm{CO}_{2}$ emission, erosion, nutrient retention, and biological activity (CIRIC, V. et al. 2012). Clayey particles capture nutrients from the environment well, but without sufficient moistening, they become inaccessible to the plants. We assume that moisture does not accumulate here, and there is no saturation of this area because of the location on top of the studied area. Thus, there is an oppression of the soil microbiota, which affects the lower degree of humification relative to the rest of the studied areas, which is confirmed in Figure 5.

From this diagram, we can observe the following distribution: sample No 1 (erosion sediment) has a higher degree of humification than sample No 2, which is not prone to erosion. Such a change of parameters is related to the dynamic re-deposition of small particles of soil. SOM binds well with the clay due to its large specific surface area of soil aggregates. Chemically bound organomineral compounds are removed from the soil profile under the influence of water erosion and accumulate in newly formed water flow areas. Prolonged hydration of such particles favourably affects the humification processes in soil and the formation of hydrophobic macromolecules. Thus, there is a thermodynamic selection of condensed HAs macromolecules and their stabilization.

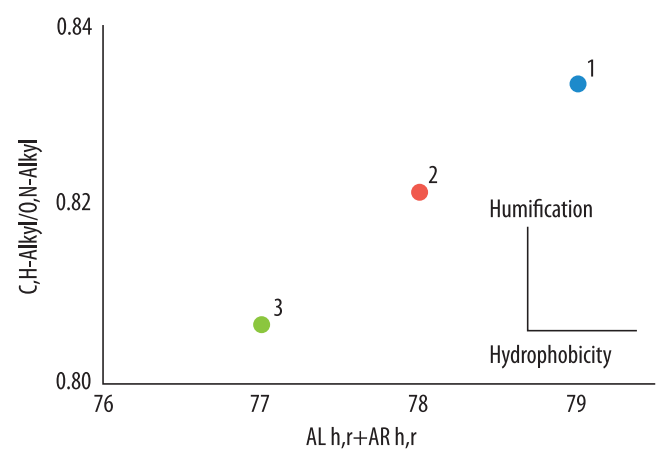

Fig. 5. The diagram of integrated indicators of the molecular composition of humic acids. AL h,r $+A R$ h, r indicates the total number of un-oxidized carbon atoms. 
Verifying the obtained results of NMR spectroscopy with remote sensing and geomorphometry data, it can be stated that non-eroded areas with high SOC content are characterized by darker colouration and intensive light absorption. This is due to the high decomposition of plant residues, microbiological activity, and a high degree of aromatic humic substances in our condition. Such areas are located on top of the site, as well as areas along roads, forest plantations, and in some low-lying areas of the terrain, where valuable soil structures are transferred through water and wind erosion.

The processes of rill water erosion are shown on space images mainly as darker and spots of SOC high values due to the re-deposition of the upper fertile fractions from the top relief elements. At the same time, the darker colouration of such areas is also affected by moistening, as such deep relief elements can retain wet soil for longer, which affects the spectral reflectivity of the soil. However, rill erosion zones do not always look like darker ones, as a movement of water flows, and repositioning of fractions is affected by micro-relief. Digital models with an ultra-high spatial resolution to identify micro-reliefs are needed.

\section{Conclusions}

To date, the method of application of RS and ${ }^{13} \mathrm{C}-\mathrm{NMR}$ spectroscopy in the investigations and digital mapping of SOC is insufficiently studied. Based on the comprehensive study of the field in long-term agricultural use with ongoing erosion processes and slopes of up to 8 degrees, it can be concluded that:

1. Sentinel-2A data can be successfully used for mapping SOC content and their uncertainty in topsoil. In our study, the highest correlation values were shown by the SWIR B12 band with a spatial resolution of $20 \mathrm{~m}$ and a spectral range of 2,190 $\mathrm{nm}$. The developed linear regression model has an average level of prediction. The maps created allowed us to estimate the spatial distribution of SOC content on the study plot.
2. Geomorphometric analysis of the territory allowed to define more precisely the relief character and directions of water flows that determine the development of erosion processes. We can conclude that in the erosion areas, due to the active movement of soil sediments by water flows, the territory is not homogeneous in SOC content. There is an active transfer of soil fractions, which forms areas of washing away and accumulation of soil sediments. In most cases, areas along forest plantations, roads, and low elevation elements are characterized by the accumulation of SOC transported by water and wind streams from the upper parts of the relief.

3. ${ }^{13} \mathrm{C}-\mathrm{NMR}$ analysis has shown that the non-eroded areas have a developed humic acid structure due to the complete process of decomposition of vegetation and microbial activity. Together, this has a direct impact on soil colouration and thus determines the nature of the spectral reflectance of soils. Areas vulnerable to sheet erosion are characterized by reduced aromaticity of SOC. These areas define such areas as less dark on space images. Despite less developed processes of SOC formation in areas of rill erosion, these areas are characterized by a darker colour of soils due to the re-deposition of fertile fractions and moisture accumulation.

Acknowledgements: The reported study was funded by RFBR according to the research project No 19-3450082. The ${ }^{13} \mathrm{C}-\mathrm{NMR}$ spectroscopy was performed in the Scientific Park of the St. Petersburg State University. Magnetic-resonance methods of investigations and elemental analyses were determined in Chemical Analysis and Materials Research Centre.

\section{REFERENCES}

Aвакumov, E.V., Cajthaml, T., Brus, J. and Frouz, J. 2013. Humus accumulation, humification, and humic acid composition in soils of two post-mining chronosequences after coal mining. Journal of Soils and Sediments 13. (3): 491-500. Available at https://doi.org/10.1007/ s11368-012-0579-9

Aвu-Hamdeh, N.H. 2003.Thermal properties of soils as affected by density and water content. Biosystems Engineering 86. 97-102. Available at https://doi. org/10.1016/S1537-5110(03)00112-0 
Angelopoulou, T., Tziolas, N., Balafoutis, A., Zalidis, G. and Bochtis, D. 2019. Remote sensing techniques for soil organic carbon estimation: A review. Remote Sensing 11. (6):676. Available at https://doi.org/10.3390/ rs11060676

Arinushrina, E.V. 1970. Soil Chemical Analysis Guide. Moscow, Moscow State University. (in Russian)

Bartholomeus, H., Schaepman, M.E., Kooistra, L., Stevens, A., Hoogmoed, W.B. and Spaargaren, O.C. 2008. Spectral reflectance based indices for soil organic carbon quantification. Geoderma 145. (1-2): 28-36. Available at https://doi.org/10.1016/j. geoderma.2008.01.010

Baude, M., Meyer, B.C. and Schindewolf, M. 2019. Land use change in an agricultural landscape causing degradation of soil based ecosystem services. Science of the Total Environment 659. 1526-1536. Available at https://doi.org/10.1016/j. scitotenv.2018.12.455

Ben-Dor, E., Inbar, Y. and Chen, Y. 1997. The reflectance spectra of organic matter in the visible near-infrared and short wave infrared region (400-2500 nm) during a controlled decomposition process. Remote Sensing of Environment 61. (1): 1-15. Available at https://doi.org/10.1016/S00344257(96)00120-4

Bhunia, G.S., Shit, P.K. and Pourghasemi, H.R. 2019. Soil organic carbon mapping using remote sensing techniques and multivariate regression model. Geocarto International 34. (2): 215-226. Available at https://doi.org/10.1080/10106049.2017.1381179

Castaldi, F., Chabrillat, S., Chartin, C., Genot, V., Jones, A.R. and van Wesemael, B. 2018. Estimation of soil organic carbon in arable soil in Belgium and Luxembourg with the LUCAS topsoil database. European Journal of Soil Science 69. (4): 592-603. Available at https://doi.org/10.1111/ejss.12553

Castaldi, F., Hueni, A., Chabrillat, S., Ward, K., Buttafuoco, G., Bomans, B., Vreys, K., Brell, M. and van Wesemael, B. 2019. Evaluating the capability of the Sentinel 2 data for soil organic carbon prediction in croplands. ISPRS Journal of Photogrammetry and Remote Sensing 147. 267282. Available at https://doi.org/10.1016/j.isprsjprs.2018.11.026

Chang, C.-W., Laird, D., Mausbach, M. and Hurburgh, C. 2001. Near-infrared reflectance spectroscopy principal components regression analyses of soil properties. Soil Science Society of America Journal 65. (2): 480-490. Available at https://doi.org/10.2136/ sssaj2001.652480x

Chen, D., Chang, N., XiaO, J., Zhou, Q. and Wu, W. 2019. Mapping dynamics of soil organic matter in croplands with MODIS data and machine learning algorithms. Science of the Total Environment 669. 844-855. Available at https://doi.org/10.1016/j. scitotenv.2019.03.151
Chukov, S.N., Ejarque, E. and Авакumov, E.V. 2017. Characterization of humic acids from tundra soils of northern Western Siberia by electron paramagnetic resonance spectroscopy. Eurasian Soil Science 50. (1): 30-33. Available at https://doi.org/10.1134/ S1064229317010057

Chukov, S.N., Lodygin, E.D. and Авакumov, E.V. 2018. Application of 13C NMR spectroscopy to the study of soil organic matter: A review of publications. Eurasian Soil Science 51. (8): 889-900. Available at https://doi.org/10.1134/S1064229318080021

Ciric, V., Manojlovic, M., Nesic, Lj. and Belic, M. 2012. Soil dry aggregate size distribution: effects of soil type and land use. Journal of Soil Science and Plant Nutrition 12. (4): 689-703. Available at http:// dx.doi.org/10.4067/S0718-95162012005000025

Conte, P., Di Stefano, C., Ferro, V., Laudicina, V.A. and Palazzolo, E. 2017. Assessing hydrological connectivity inside a soil by fast-field-cycling nuclear magnetic resonance relaxometry and its link to sediment delivery processes. Environmental Earth Sciences 76. (15):526. Available at https://doi. org/10.1007/s12665-017-6861-9

Desprats, J.F., Raclot, D., Rousseau, M., Cerdan, O., Garcin, M., Bissonnais, Y.L., Slimane, A.B., Fouche, J. and Monfort-Climent, D. 2013. Mapping linear erosion features using high and very high resolution satellite imagery. Land Degradation $\mathcal{E}$ Development 24. (1): 22-32. Available at https://doi.org/10.1002/ ldr.1094

Dou, X., Wang, X., LiU, H., Zhang, X., Meng, L., Pan, Y., YU, Z. and CuI, Y. 2019. Prediction of soil organic matter using multi-temporal satellite images in the Songnen Plain, China. Geoderma 356. 113896. Available at https://doi.org/10.1016/j.geoderma.2019.113896

Dube, T., Muchena, R., Masocha, M. and Sноко, C. 2018. Estimating soil organic and aboveground woody carbon stock in a protected dry Miombo ecosystem, Zimbabwe: Landsat 8 OLI data applications. Physics and Chemistry of the Earth, Parts A/B/C 105. 154-160. Available at https://doi.org/10.1016/j. pce. 2018.03 .007

EsCADAFAL, R. 1989. Remote sensing of arid soil surface color with Landsat thematic mapper. Advances in Space Research 9. (1): 159-163. Available at https:// doi.org/10.1016/0273-1177(89)90481-X

Emadi, M., Taghizadeh-Mehrjardi, R., Cherati, A., Danesh, M., Mosavi, A. and Scholten, T. 2020. Predicting and Mapping of Soil Organic Carbon Using Machine Learning Algorithms in Northern Iran. Remote Sensing 12. (14):2234. Available at https://doi.org/10.3390/rs12142234

Frankl, A., Prêtre, V., Nyssen, J. and Salvador, P.G. 2018. The success of recent land management efforts to reduce soil erosion in northern France. Geomorphology 303. 84-93. Available at https://doi. org/10.1016/j.geomorph.2017.11.018 
Gabbasova, I.M., Suleimanov, R.R., Khabirov, I.K., Komissarov, M.A., Fruehauf, M., Liebelt, P., Garipov, T.T., Sidorova, L.V. and Khaziev, F.KH. 2016. Temporal changes of eroded soils depending on their agricultural use in the southern Cis-Ural region. Eurasian Soil Science 49. (10): 1204-1210. Available at https://doi.org/10.1134/S1064229316100070

Gholizadeh, A., Žižala, D., Saberioon, M. and BORŮVKA, L. 2018. Soil organic carbon and texture retrieving and mapping using proximal, airborne and Sentinel-2 spectral imaging. Remote Sensing of Environment 218. 89-103. Available at https://doi. org/10.1016/j.rse.2018.09.015

Gitelson, A.A., Kaufman, Y.J. and Merzlyak, M.N. 1996. Use of a green channel in remote sensing of global vegetation from EOS-MODIS. Remote Sensing of Environment 58. (3): 289-298. Available at https:// doi.org/10.1016/S0034-4257(96)00072-7

Golosov, V., Yermolaev, O., Rysin, I., Vanmaercke, M., Medvedeva, R. and Zaytseva, M. 2018. Mapping and spatial-temporal assessment of gully density in the Middle Volga region, Russia. Earth Surface Processes and Landforms 43. (13): 2818-2834. Available at https://doi.org/10.1002/esp.4435

Gomez, C., Coulouma, G. and Lagacherie, P. 2012. Regional predictions of eight commonsoil properties and their spatial structures from hyperspectral Vis-NIR data. Geoderma 189-190. 176-185. Available at https://doi.org/10.1016/j.geoderma.2012.05.023

Gopp, N.V., Nechaeva, T.V., Savenkov, O.A., Smirnova, N.V. and Smirnov, V.V. 2017. Indicative capacity of NDVI in predictive mapping of the properties of plow horizons of soils on slopes in the south of Western Siberia. Eurasian Soil Science 50. 1332-1343. Available at https://doi.org/10.1134/ S1064229317110060

Guo, B., Yang, G., Zhang, F., Han, F. and Liu, C. 2018. Dynamic monitoring of soil erosion in the upper Minjiang catchment using an improved soil loss equation based on remote sensing and geographic information system. Land Degradation $\mathcal{E}$ Development 29. (3): 521-533. Available at https:// doi.org/10.1002/ldr.2882

Huete, A., Didan, K., Miura, T., Rodriguez, E.P., Gao, X. and Ferreira, L.G. 2002. Overview of the radiometric and biophysical performance of the MODIS vegetation indices. Remote Sensing of Environment 39. (1): 195-213. Available at https://doi.org/10.1016/ S0034-4257(02)00096-2

Huete, A.R. 1988. A soil-adjusted vegetation index (SAVI). Remote Sensing of Environment 25. (3): 295-309. Available at https://doi.org/10.1016/00344257(88)90106-X.

IUSS Working Group WRB, 2014. World reference base for soil resources. In: International Soil Classification System for Naming Soils and Creating Legends for Soil Maps. World Soil Resources Reports No. 106. Rome, FAO.
Jaber, S.M., Lant, C.L. and Al-Qinna, M.I. 2011. Estimating spatial variations in soil organic carbon using satellite hyperspectral data and map algebra. International Journal of Remote Sensing 32. (18): 5077-5103. Available at https://doi.org/10.1080/0143 1161.2010.494637

Jenson, S.K. and Domingue, J.O. 1988. Extracting topographic structure from digital elevation data for geographic information system analysis. Photogrammetric Engineering and Remote Sensing 54. (11): 1593-1600.

Kattsov, V.M. (ed.) 2017. Report on Climate Risks in the Russian Federation. Saint Petersburg, Saint Petersburg State University. (in Russian)

Khan, J., Aelst, S.V., and Zamar, R. 2010. Fast robust estimation of prediction error based on resampling. Computational Statistics \& Data Analysis 54. 3121-3130. Available at https://doi.org/10.1016/j.csda.2010.01.031

Khaziev, F.Kн. (ed.) 1995. Soils of Bashkortostan. Vol. 1. Ecologic-Genetic and Agro-productive Characterization. Ufa, Gilem. (in Russian).

Lal, R., Kimble, J.M., Follet, R.F. and Stewart, B.A. (eds.) 2001. Assessment Methods for Soil Carbon. Boca Raton, FL, USA, Lewis Publishers.

Leh, M., Bajwa, S. and Chaubey, I. 2013. Impact of land use change on erosion risk: An integrated remote sensing, geographic information system and modelling methodology. Land Degradation \& Development 24. (5): 409-421. Available at https://doi.org/10.1002/ ldr. 1137

Lodygin, E.D., Beznosikov, V.A. and VANChikova, E.V. 2001. Functional groups of fulvic acids from gleyic peaty-podzolic soil. Eurasian Soil Science 34. (4): 382-386.

Lodygin, E.D., Beznosikov, V.A. and Vasilevich, R.S. 2014. Molecular composition of humic substances in tundra soils (13C-NMR spectroscopic study). Eurasian Soil Science 47. 400-406. Doi: 10.1134/ S1064229314010074

Magliulo, P., Russo, F. and Lo Curzio, S. 2020. Detection of permanently eroded land surfaces through multi-temporal analysis of Landsat data: A case study from an agricultural area in southern Italy. Environmental Earth Sciences 79. (3): 73. Available at https://doi.org/10.1007/s12665-020-8814-y

Marsett, R.C., Qi, J., Heilman, P., Biedenbender, S.H., Watson, M.C., Amer, S., Weltz, M., Goodrich, D. and MARsett, R. 2006. Remote sensing for grassland management in the arid Southwest. In Rangeland Ecology and Management 59. (5): 530-540. Available at https://doi.org/10.2111/05-201R.1

Mouazen, A.M., Maleki, M.R., de Baerdemaeker, J. and RAMON, H. 2007. On-line measurement of some selected soil properties using a VIS-NIR sensor. Soil and Tillage Research 93. (1): 13-27. Available at https:// doi.org/10.1016/j.still.2006.03.009

Mulder, V.L., de Bruin, S., Schaepman, M.E. and MAYR, T.R. 2011. The use of remote sensing in soil and terrain mapping - A review. Geoderma 162. (1): 
1-19. Available at https://doi.org/10.1016/j.geoderma.2010.12.018

Nampak, H., Pradhan, B., Rizeei, H.M. and Park, H.-J. 2018. Assessment of land cover and land use change impact on soil loss in a tropical catchment by using multi-temporal SPOT-5 satellite images and Revised Universal Soil Loss Equation model. Land Degradation \& Development 29. (10): 3440-3455. Available at https://doi.org/10.1002/ldr.3112

Nellis, M.D. and Briggs, J.M. 1992. Transformed vegetation index for measuring spatial variation in drought impacted biomass on Konza Prairie, Kansas. Transactions of the Kansas Academy of Science 95. (1-2): 93-99. Available at https://doi. org $/ 10.2307 / 3628024$

Nocita, M., Stevens, A., van Wesemael, B., Aitkenhead, M., Bachmann, M., Barthès, B., Ben Dor, E., Brown, D.J., Clairotte, M., Csorba, A., Dardenne, P., Demattê, J.A. M., Genot, V., Guerrero, C., Knadel, M., Montanarella, L., Noon, C., Ramirez-Lopez, L., Robertson, J., SAKaI, H., Soriano-Disla, J.M., ShePherd, K.D., Stenberg, B., Towett, E.K., Vargas, R. and Wetterlind, J. 2015. Soil spectroscopy: An alternative to wet chemistry for soil monitoring. Advances in Agronomy 132. 139-159. Available at https://doi.org/10.1016/ bs.agron.2015.02.002

Panagos, P., Borrelli, P. and Meusburger, K. 2015. A new European slope length and steepness factor (LS-Factor) for modelling soil erosion by water. Geosciences 5. (2): 117-126. Available at https://doi. org/10.3390/geosciences5020117

Phinzi, K. and Ngetar, N.S. 2019. The assessment of water-borne erosion at catchment level using GIS-based RUSLE and remote sensing: A review. International Soil and Water Conservation Research 7. (1): 27-46. Available at https://doi.org/10.1016/j. iswcr.2018.12.002

Polyakov, V. and Aвакumov, E.V. 2020. Humic acids isolated from selected soils from the Russian Arctic and Antarctic: Characterization by two-dimensional 1H-13C HETCOR and 13C CP/Mas NMR spectroscopy. Geosciences 10. (1): 15. Available at https://doi. org/10.3390/geosciences10010015

Pouget, M., Madeira, J., Le Floch, E. and Kamal, S. 1990. Caracteristiques spectrales des surfaces sableuses de la region cotiere Nord-Ouest de l'Egypte: Application aux donandes satellitaires SPOT. 2eme JoumCes de Tanddetection: Caracterisation et suivi des milieux terrestres en regions arides et tropicales. 4-6/12/1990. Collection Colloques et Seminaires, Paris, ORSTOM.

Prudnikova, E.Yu. and Savin, I.Yu. 2015. Satellite assessment of dehumification of arable soils in Saratov region. Eurasian Soil Science 48. (5): 533-539. Available at https://doi.org/10.1134/ S1064229315050075
Quideau, S.A., Anderson, M.A., Graham, R.C., Сhadwick, O.A. and Trumbore, S.E. 2000. Soil organic matter processes: Characterization by $13 \mathrm{C}$ NMR and 14C measurements. Forest Ecology and Management 138. (1): 19-27. Available at https://doi.org/10.1016/ S0378-1127(00)00409-6

R Development Core Team, 2015. R: A Language and Environment for Statistical Computing. Vienna, $\mathrm{R}$ Foundation for Statistical Computing. Available at http://www.Rproject.org/.

Rock, B.N., Williams, D.L., and Vogelmann, J.E. 1985. Field and airborne spectral characterization of suspected damage in red spruce (picea rubens) from Vermont. NASA Technical Reports, ID 19860052270. Greenbelt, MD, USA. NASA Goddard Space Flight Center. Available at https://ntrs.nasa.gov/search.jsp?R=19860052270

Rouse, J.W. JR., HaAs, R.H., Schell, J.A. and DeERing, D.W. 1974. Monitoring vegetation systems in the Great Plains with ERTS. NASA Special Publication 351. 309. Greenbelt, MD, USA. NASA Goddard Space Flight Center

RozhKov, V.A. (ed.) 2006. Soil Science. Moscow, Nauka. (in Russian)

RStudio, 2015. RStudio: Integrated Development Environment for R. Boston, MA. USA, Available at http://www.r-studio.com

Rumpel, C., Chaplot, V., Ciais, P., Chabbi, A., Bouahom, B. and Valentin, C. 2014. Composition changes of eroded carbon at different spatial scales in a tropical watershed suggest enrichment of degraded material during transport. Biogeosciences 11. (12): 3299-3305. Available at https://doi.org/10.5194/bg-11-3299-2014

Savin, I.Yu., Zhogolev, A.V. and Prudnikova, E.Yu. 2019. Modern trends and problems of soil mapping. Eurasian Soil Science 52. (5): 471-480. Available at https://doi.org/10.1134/S1064229319050107

Sepuru, T.K. and Dube, T. 2018. An appraisal on the progress of remote sensing applications in soil erosion mapping and monitoring. Remote Sensing Applications: Society and Environment 9.1-9. Available at https://doi.org/10.1016/j.rsase.2017.10.005

Simpson, M.J., Otтo, A. and FenG, X. 2008. Comparison of solid-state Carbon-13 nuclear magnetic resonance and organic matter biomarkers for assessing soil organic matter degradation. Soil Science Society of America Journal 72. (1): 268-276. Available at https:// doi.org/10.2136/sssaj2007.0045

Sobol, N.V., Gabbasova, I.M. and Komissarov, M.A. 2015. Impact of climate changes on erosion processes in Republic of Bashkortostan. Arid Ecosystems 5. (4): 216-221. Available at https://doi.org/10.1134/ S2079096115040137

SoкоLov, A.V. 1975. Agrochemical Methods of Soil Studies. Moscow, Nauka. (in Russian)

SulEYMANov, A.R. 2019. Geomorphometric and geoinformation approach to meliorative evaluation of the territory. In Climate Change Impacts on Hydrological Processes and Sediment Dynamics: Measurement, 
Modelling and Management. Eds.: Chalov, S., Golosov, V., Li, R. and Tsyplenkov, A. Cham, Springer International Publishing, 72-75. Available at https://doi.org/10.1007/978-3-030-03646-1_14

Suleymanov, R., Saifullin, I., Komissarov, M., Gabbasova, I., Suleymanov, A. and Garipov, T. 2019. Effect of phosphogypsum and turkey litter on the erodibility of agrochernozems of the southern Cis-Ural (Russia) under artificial heavy rainfall. Soil $\mathcal{E}$ Environment 38. (1): 81-89. Available at https:// doi.org/10.25252/SE/19/71730

Suleymanov, R., Zaykin, S., Suleymanov, A., Авакumov, E. and Kostecki, J. 2020a. Changes in basic soil physical properties of agrochernozyems under no-till conditions. Yüzüncü Yıl Üniversitesi Tarm Bilimleri Dergisi 30. 963-972. Available at https://doi.org/10.29133/yyutbd.754479

Suleymanov, R., Yaparov, I., Saifullin, I., Vildanov, I., Shirokikh, P., Suleymanov, A., Komissarov, M., Liebelt, P., Nigmatullin, A. and Khamidullin, R. 2020b. The current state of abandoned lands in the northern forest-steppe zone at the Republic of Bashkortostan (Southern Ural, Russia). Spanish Journal of Soil Science 10. (1): 29-44. Available at https://doi.org/10.3232/SJSS.2020.V10.N1.03

SwIFT, R.S. 1996. Organic matter characterization. In Methods of Soil Analysis, Part 3. Chemical Methods. Eds.: Sparks, D.L., Page, A.L., Helmke, P.A. and Loepert, R.H., SSSA Book Series No 5., Madison, WI, USA, SSSA-ASA, 1011-1069. Available at https://doi.org/10.2136/sssabookser5.3.c35

Tucker, C.J. 1979. Red and photographic infrared linear combinations for monitoring vegetation. Remote Sensing of Environment 8. (2): 127-150. Available at https://doi.org/10.1016/0034-4257(79)90013-0

Vaudour, E., Gomez, C., Fouad, Y. and Lagacherie, P. 2019. Sentinel-2 image capacities to predict common topsoil properties of temperate and Mediterranean agroecosystems. Remote Sensing of Environment 223. 21-33. Available at https://doi. org/10.1016/j.rse.2019.01.006
Viscarra Rossel, R.A., Minasny, B., Roudier, P. and McBratney, A.B. 2006a. Colour space models for soil science. Geoderma 133. (3-4): 320-337.

Viscarra Rossel, R.A., Walvoort, D.J.J., McBratney, A.B., JANiK, L.J. and SkJEmstad, J.O. 2006b. Visible, near infrared, mid infrared or combined diffuse reflectance spectroscopy for simultaneous assessment of various soil properties. Geoderma 131. (1): 59-75. Available at https://doi.org/10.1016/j. geoderma.2005.03.007

WAng, L., HuAng, J., Du, Y., Hu, Y. and Han, P. 2013. Dynamic assessment of soil erosion risk using Landsat TM and HJ satellite data in Danjiangkou Reservoir Area, China. Remote Sensing 5. (8): 38263848. Available at https://doi.org/10.3390/rs5083826

Xiao, X., Zhang, Q., Braswell, B., Urbanski, S., Boles, S., Wofsy, S., Moore, B. and Ojima, D. 2004. Modeling gross primary production of temperate deciduous broadleaf forest using satellite images and climate data. Remote Sensing of Environment 91. (2): 256-270. Available at https://doi.org/10.1016/j. rse.2004.03.010

YANG, X., Zhang, X., Lv, D., Yin, S., Zhang, M., ZHU, Q., YU, Q. and LiU, B. 2020. Remote sensing estimation of the soil erosion cover-management factor for China's Loess Plateau. Land Degradation $\mathcal{E}$ Development 31. (11): 1-14. Available at https:// doi.org/10.1002/ldr.3577

Yermolaev, O.P. 2017. Geoinformation mapping of soil erosion in the Middle Volga region. Eurasian Soil Science 50. (1): 118-131. Available at https://doi. org/10.1134/S1064229317010070 